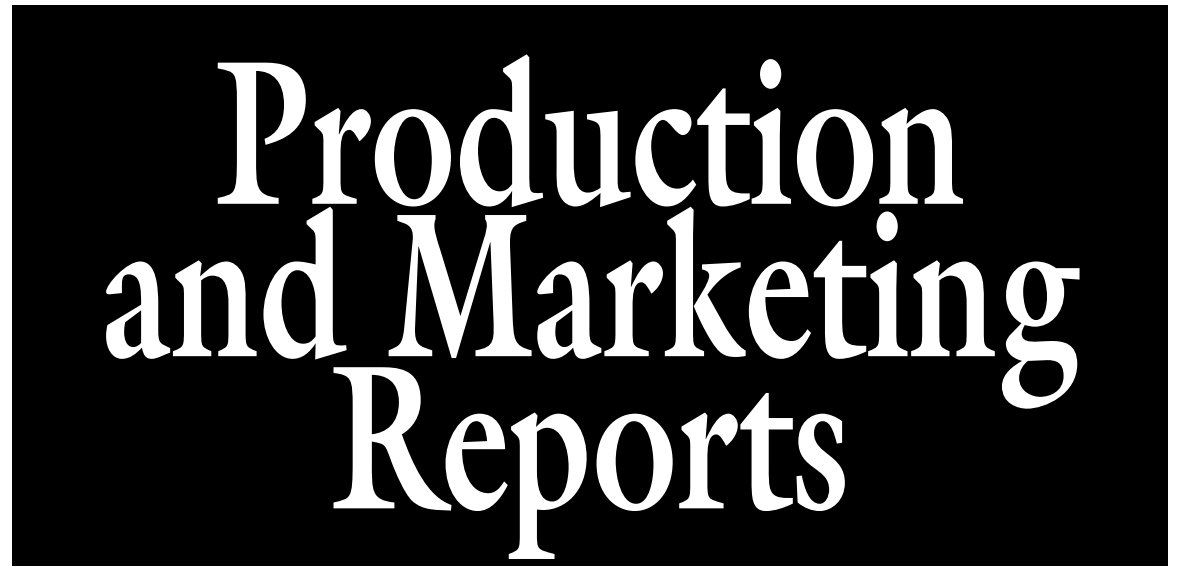

\section{Consumer Perceptions of Green Industry Retailers}

\author{
Julie H. Campbell ${ }^{1,3}$ and Benjamin L. Campbell ${ }^{2}$
}

ADDITIONAL INDEX wORDs. Baby Boomer, Generation X, home improvement center, independent garden center, mass merchandiser, Millennial

SUMMARY. A survey of Connecticut consumers was used to investigate perceptions of various green industry retailers. Consumer perceptions of independent garden centers (IGC), home improvement centers (HIC), and mass merchandisers (MM) business practices and their perceived value were assessed. Analysis of variance and ordinary least squares regression models were used to analyze the data. Results indicated that customer service, knowledgeable staff, and high-quality plants are important factors when consumers are deciding where to shop. IGCs were ranked highest in perceived customer service, knowledgeable staff, and plant quality, followed by HICs. MMs were ranked lowest for the majority of measured business practices, with the most notable exception being price. Additionally, IGCs, HICs, and MMs are perceived differently across age cohorts.

$\mathrm{I}$ $\mathrm{n}$ the early 2000 s, green industry wholesale and retail segments were rapidly growing as the housing market expanded, thereby fueling perceived strength and stability within the industry (Hall, 2010; Perez et al., 2016). However, the recession of 2007-08 caused many wholesale growers to decrease production or end their business entirely. In Georgia,

Received for publication 4 Oct. 2018. Accepted for publication 11 Feb. 2019.

Published online 26 March 2019.

This research was funded via a grant from the USDA/ Connecticut Specialty Crop Block Grant Program

${ }^{1}$ Department of Horticulture, University of Georgia, 325 Hoke Smith Building, Athens, GA 30602

${ }^{2}$ Department of Agricultural and Applied Economics, University of Georgia, 147 Cedar Street, Athens, GA 30602

${ }^{3}$ Corresponding author. E-mail: julie.campbell@uga. edu.

This is an open access article distributed under the CC BY-NC-ND license (https://creativecommons.org/ licenses/by-nc-nd/4.0/).

https://doi.org/10.21273/HORTTECH04205-18 between 2007 and 2012, green industry production levels and farm gate values decreased by $50 \%$ and $33 \%$, respectively (Campbell et al., 2017a). However, the economy has experienced recovered growth; therefore, production and consumer spending have increased. Gardeners in the United States reported spending $\$ 47.8$ billion in 2017 on lawn and garden supplies, which equates to $\approx \$ 503$ per household (Garden Research, 2018). Spending per household has increased 26\% since 2009 , with $\approx 75 \%$ of households participating in gardening in 2016 (Garden Research, 2010, 2017).

As households either return to the market or increase their spending on lawn and garden supplies, retailers must become increasingly knowledgeable about how they are viewed by current and potential customers. Yue and Behe (2008) found that consumers purchasing foliage and garden plants were more likely to choose a "box store" because of their reputation for convenience and lower prices. Furthermore, they found that younger consumers were less likely to shop at box stores, as were higher-income consumers, for their retail floral needs. However, younger consumers were more likely to shop at direct-to-consumer floral retail outlets. In a study by Satterthwaite et al. (2006), convenience was the primary reason for shopping at independent garden centers (IGCs), followed by service, quality, and price. The primary reasons for shopping at chain outlets were convenience and price, with quality and service ranking lower on the list of consumer priorities.

Firms focusing solely on price or convenience may neglect other important issues that directly impact consumer views of retail outlets. Worker wages (Lutz, 2015; Meyersohn, 2018; Tuttle, 2016), pollinator-friendly issues (Campbell et al., 2017b; Rihn and Khachatryan, 2016), and product delivery (Chao, 2016; Danziger, 2018; Leaman, 2018; Manlapas, 2018) are some examples of new trends that are shaping consumer expectations when making retail purchase decisions regarding green industry and nongreen industry products. Understanding how IGCs compare with home improvement centers (HICs), such as Home Depot (Atlanta, GA) and Lowe's (Moorseville, NC), and mass merchandisers (MMs), such as Wal-Mart (Bentonville, AR) and Target (Minneapolis, MN), is essential for retailers if they wish to make informed marketing and production decisions.

Anecdotal evidence has suggested that consumers view IGCs as having higher prices and higher quality when compared with HICs and MMs (Curran, 2013). Safley and Wohlgenant (1995) performed one of the few studies of this topic. They found that quality plants, plant selection, location, and knowledgeable sales staff were the main reasons why consumers choose to make purchases at retail outlets. However, a gap in the literature exists regarding understanding plant buyer perceptions of varying production/business practices (e.g., paying workers a living wage, home delivery, and being a valuable member of the community), especially as they relate to different retail outlets (i.e., IGC, MM, and HIC) and across age cohorts. Understanding whether 
there are perception differences and, if so, how these perceptions relate across key consumer demographics can provide valuable information to green industry firms.

\section{Materials and methods}

During Summer 2016 and Fall 2016, an online consumer survey was implemented. It asked consumers questions related to their perceptions of various business practices and production practices across retailer types (i.e., IGC, HIC, and MM) as well as to their plant purchasing behaviors and demographics. Approximately 1400 Connecticut residents from the Lightspeed Global Market Insite (GMI) panel database (Lightspeed Research, Warren, NJ) were surveyed. Connecticut was the only state sampled because the funding agency was interested in the Connecticut market. Connecticut does provide an interesting market because its green industry is the largest agricultural sector in terms of direct sales and economic impact (Lopez et al., 2015). Additionally, the State of Connecticut Council for Agricultural Development has been tasked with increasing local food expenditures to $5 \%$ or more of total food expenditures by 2020 (State of Connecticut, 2011). This state goal indicates a desire by Connecticut policymakers to increase the purchasing of locally produced products. Although plants are not included in the goal, IGCs could experience an increase in sales because they are subsequently viewed as part of the "buy local" movement (Sparks, 2017).

Consumers within the GMI database were contacted by GMI about their willingness to participate in the survey. Consumers willing to participate were directed to the survey via a web link. Only respondents residing in Connecticut who were 18 years or older were allowed to complete the survey. The survey required $\approx 20 \mathrm{~min}$ and had a response rate of $\approx 80 \%$. To capture the responses of actively participating respondents, researchers included filter questions that were placed strategically throughout the survey. These questions asked respondents to choose a specific answer. This method reduced the likelihood of capturing data from participants who were disengaged and/or randomly providing answers (i.e., a wrong answer likely implied that the respondent was not actively engaged in reading the survey questions).

This study asked plant-buying consumers several questions regarding the importance of various retail outlet business and production practices, satisfaction across retailers based on various business and production practices, and perceptions of quality, price, and quality for price across retailers. Answers were measured on 100-point line scales specific to each of the three points of emphasis listed here. Each respondent could click on any point on the graphically displayed continuous line. When asked about the importance of a business or production practice in the decision to shop at a specific retailer, respondents were asked to assign a score related to the importance of $(0=$ not at all important, $50=$ moderately important, and $100=$ extremely important) of a business or production practice in their decision to shop at a specific retailer. To assess respondent satisfaction with various business and production practices across retailers, respondents were asked to assign a score $(0=\mathrm{ex}-$ tremely dissatisfied; $50=$ neither satisfied nor dissatisfied; $100=$ extremely

Table 1. Descriptive statistics of the sample of Connecticut survey respondents who had purchased plants as determined by a 2016 survey of Connecticut residents.

\begin{tabular}{|c|c|c|}
\hline & \multicolumn{2}{|c|}{ Plant buyers only } \\
\hline & Mean & SD \\
\hline \multicolumn{3}{|l|}{ Age (years) } \\
\hline Mean & 46 & 17 \\
\hline Median & 45 & - \\
\hline \multicolumn{3}{|l|}{ Age generation ${ }^{z}$} \\
\hline Baby Boomer or older & $40 \%$ & $49 \%$ \\
\hline Generation X & $37 \%$ & $48 \%$ \\
\hline Millennial or younger & $21 \%$ & $41 \%$ \\
\hline Race $(1=$ Caucasian $)$ & $85 \%$ & $35 \%$ \\
\hline $\operatorname{Sex}(1=$ male $)$ & $28 \%$ & $45 \%$ \\
\hline \multicolumn{3}{|l|}{ Urbanicity } \\
\hline Rural & $20 \%$ & $40 \%$ \\
\hline Suburban & $71 \%$ & $45 \%$ \\
\hline Urban & $9 \%$ & $28 \%$ \\
\hline \multicolumn{3}{|l|}{ Household income (in 2015) } \\
\hline Mean & $\$ 75,820$ & $\$ 44,716$ \\
\hline Median & $\$ 72,682$ & - \\
\hline \multicolumn{3}{|l|}{ Housing status } \\
\hline Detached & $66 \%$ & $48 \%$ \\
\hline Other & $34 \%$ & $48 \%$ \\
\hline Adults in household (no.) & 2.27 & 0.95 \\
\hline Children ( $<18$ years) in household & 0.52 & 0.92 \\
\hline \multicolumn{3}{|l|}{ Purchasing behaviors } \\
\hline Plant buyer $(1=$ yes $)$ & $100 \%$ & - \\
\hline Plant experience $\mathrm{y}^{\mathrm{y}}$ & $\$ 22.93$ & $\$ 18.71$ \\
\hline \multicolumn{3}{|l|}{ Plants } \\
\hline Annual flowering & $55 \%$ & $50 \%$ \\
\hline Vegetable & $55 \%$ & $50 \%$ \\
\hline Herbs & $47 \%$ & $50 \%$ \\
\hline Flowering perennial & $46 \%$ & $50 \%$ \\
\hline Flowering shrub & $32 \%$ & $47 \%$ \\
\hline Nonflowering shrub & $11 \%$ & $31 \%$ \\
\hline Fruit-producing tree & $12 \%$ & $32 \%$ \\
\hline Evergreen tree/shrub & $9 \%$ & $29 \%$ \\
\hline Shade tree & $6 \%$ & $24 \%$ \\
\hline Indoor flowering potted plant & $33 \%$ & $47 \%$ \\
\hline Other & $5 \%$ & $21 \%$ \\
\hline Observations (no.) & \multicolumn{2}{|c|}{1,019} \\
\hline
\end{tabular}

${ }^{\mathrm{z}}$ Baby Boomers or older (born 1964 or earlier), Generation X (born between 1965 and 1984), Millennials or younger (born 1985 or after).

${ }^{y}$ Plant experience refers to the amount of money spent on plants during the past year. 
satisfied) to their satisfaction level with that practice for each retailer. Finally, to assess quality, price, and quality for price, respondents were asked to assign a score $(0=$ lowest on market $50=$ market average $; 100=$ highest on market) based on their opinions regarding these characteristics for IGCs, HICs, and MMs. To determine quality and price, respondents evaluated these two plant characteristics independently; however, when evaluating quality for price paid, respondents based their opinions on plants sold at particular retail outlets.

The median age of the respondent sample was 45 years, with a median 2015 household income of $\$ 72,682$ (Table 1). In comparison, the median age and household income of the Connecticut population were 40.6 years and $\$ 71,755$ (U.S. Census Bureau, 2010). The survey sample was $81 \%$ Caucasian, with an average household size of 2.7 persons. The Connecticut population was $80 \%$ Caucasian, with an average household size of 2.6 persons (U.S. Census Bureau, 2017). After comparing age, household income, race, and household size, the sample appeared to be representative of the Connecticut population. Because no standard errors were provided for the U.S. Census Bureau population estimates, statistical testing could not be performed to evaluate whether the sample was statistically equivalent for the demographics discussed. The only sample demographic variable that appeared different from that of the U.S. Census Bureau estimates for Connecticut was sex. The sample was $30 \%$ male, which was lower than the estimated $49 \%$ male reported by the U.S. Census Bureau (2017) for Connecticut. Oversampling of women was performed by design because women have been noted as the primary shopper in the majority of households (Flagg et al., 2013; Wolfe, 2013; Zepeda, 2009).

Analysis of variance with post hoc Tukey's multiple comparison correction was used to test for differences in perceptions across retailer types as well as differences in perceptions across retailer types and age. Age was included as a treatment effect because it has been shown that various age groups (e.g., Baby Boomers and Millennials) can have different preferences when purchasing plants (Behe et al.,
2016). For this study, we used three age cohorts, Baby Boomers or older (born 1964 or earlier), Generation X (born between 1965 and 1984), and Millennials or younger (born 1985 or after). Hereafter, we refer to Baby Boomers or older individuals as Baby Boomers and to Millennials or younger individuals as Millennials.

To gain a better understanding of how demographics might impact consumer perceptions of quality, price, and quality for price across retailers, several ordinary least squares (OLS) regression models were used. To determine the role of demographics in how consumers view price, quality, and quality for price for different retailers, the dependent variables for the OLS models were calculated as shown in Eq. [1]:

$$
\Upsilon_{j m i}=R_{m n i}-S_{m v i}
$$

where $\Upsilon$ is the difference in the $j^{\text {th }}$ retailer comparison (i.e., IGC vs. $\mathrm{HIC}$, IGC vs. MM, HIC vs. MM) for the $\mathrm{m}^{\text {th }}$ measure of interest (i.e., quality, price, quality for price) by the $\mathrm{i}^{\text {th }}$ respondent, $R$ and $S$ represent ratings, and $\mathrm{n}$ and $\mathrm{v}$ represent different retailers. Therefore, using Eq. [1], a dependent variable encompassing the independent differences in ratings of quality, price, and quality for price for two retailers was constructed. Using the dependent variable in this format created a variable with a range from -100 (i.e., $R_{m n i}=$ 0 and $\left.S_{m v i}=100\right)$ to 100 (i.e., $R_{m n i}=$ 100 and $S_{m v i}=0$ ).

Given the structure of the dependent variable, two potential problems arose when using OLS. The first was the censoring of dependent variables, given the range of -100 and 100 , for differences. Examining the frequency of endpoints $(-100$ and $100)$ is one way to assess the potential impact of censoring. Censoring at the endpoints ranged from $0 \%$ to $1 \%$, except when the IGC was compared with the MM regarding quality and price, which had censoring of $4 \%$ and $3 \%$, respectively. A tobit model was used to test the robustness of the results and found trends similar to those for the OLS models. Second, the decision process for quality, price, and quality for price could be considered a simultaneous process, which would imply that a system of equations (i.e., seemingly unrelated regression) may be appropriate. However, inclusion of the same variables in the model would produce the same results as those of individual OLS models. As a result, OLS estimates with robust standard errors (Huber, 1967; White, 1980, 1982) are presented and discussed.

\section{Results and discussion}

B U S I N E S / P R O D U C T I O N PRACTICE IMPORTANCE. For all buyers, knowledgeable staff, customer service, lowest price, and high-quality plants were the most important drivers for respondents when choosing a retailer (Table 2). Conversely, being a valuable community member was near the bottom of practices that respondents considered when deciding where to shop. Similar practices were found to be important across all variables, including age. Only a slight difference was observed for some of the practices. Millennials (73 ratings) were only slightly less concerned about knowledgeable staff compared with Baby Boomers (77 ratings) and Generation $\mathrm{X}$ (77 ratings) respondents.

The three largest differences quantified by this study were the estimates associated with lowest price, highquality plants, and being a valuable member of the community. Baby Boomers and Generation $\mathrm{X}$ respondents viewed low price and high quality as extremely important when deciding where to shop, whereas Millennials shifted the importance of these qualities significantly downward, near the moderately important range. Millennials attributed more importance to a retailer that is a valuable member of the community compared with the other age cohorts. This result can be misleading, however, because Millennials only placed the status of being a valuable member of the community in the "not at all important to moderately important" range, but their rating was significantly higher than that of other generations surveyed.

B US I NES S / P R O D U C T I O N PRACTICE SATISFACTION ACROSS RETAILERS. Plant buyers reported varying satisfaction levels for business and production practices across retailers (Table 3). Respondents consistently reported higher satisfaction levels for IGCs compared with HICs and MMs for all business and 
Production and Marketing Reports

Table 2. Importance of business/production practices when choosing a plant retailer as determined by a 2016 survey of plant buyers residing in Connecticut.

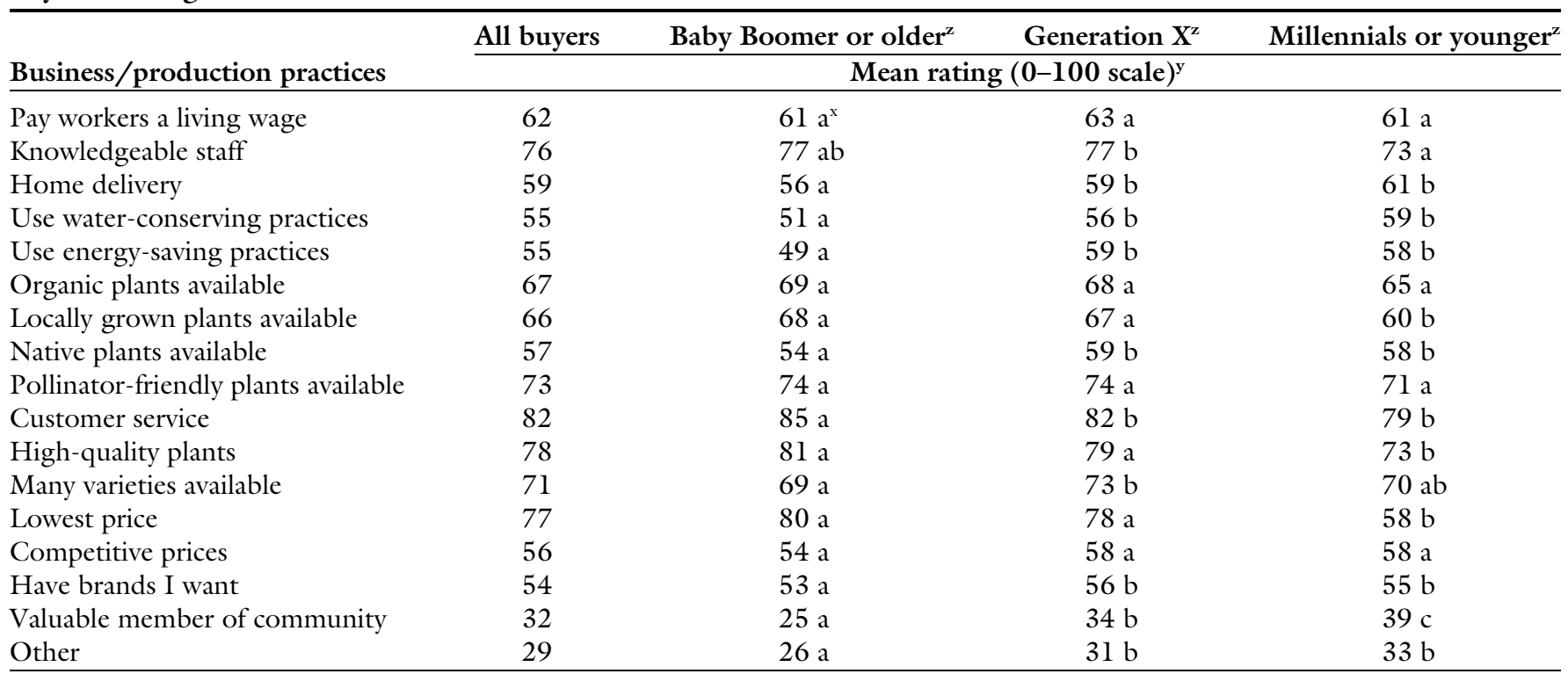

${ }^{\mathrm{z}}$ Baby Boomers or older (born 1964 or earlier), Generation X (born between 1965 and 1984), Millennials or younger (born 1985 or after).

${ }^{y}$ Respondents chose their response based on a 100 -point importance scale where $0=$ not at all important, $50=$ moderately important, and $100=$ extremely important.

${ }^{x}$ Letters indicate significance using an analysis of variance with Tukey's honestly significant difference multiple comparison correction. The same letter in a row indicates no significant difference at the 0.10 level, whereas different letters indicate significant differences at the 0.10 level.

Table 3. Importance of business/production practices and price/quality comparisons associated with specific plant retailers as determined by a 2016 survey of plant buyers residing in Connecticut.

Nursery/greenhouse garden center Home improvement center ${ }^{\mathrm{z}}$ Mass merchandiser $^{\mathrm{z}}$ Mean rating (0-100 scale $)^{\mathrm{y}}$

Business/production practices

Pay workers a living wage

Knowledgeable staff

Use water-conserving practices

Use energy-saving practices

Organic plants available

Locally grown plants available

Native plants available

Pollinator-friendly plants available

Customer service

High-quality plants

Many varieties available

Lowest price

Competitive prices

Have brands I want

Valuable member of community

Home delivery

Other

Price/quality practices

Price

Quality

Quality for price paid

$61 \mathrm{a}^{x}$
$75 \mathrm{a}$
$63 \mathrm{a}$
$61 \mathrm{a}$
$64 \mathrm{a}$
$71 \mathrm{a}$
$68 \mathrm{a}$
$65 \mathrm{a}$
$72 \mathrm{a}$
$74 \mathrm{a}$
$72 \mathrm{a}$
$53 \mathrm{a}$
$59 \mathrm{a}$
$59 \mathrm{a}$
$57 \mathrm{a}$
$46 \mathrm{a}$
$36 \mathrm{a}$

$55 \mathrm{~b}$

$59 \mathrm{~b}$

$53 \mathrm{~b}$

$53 \mathrm{~b}$

$53 \mathrm{~b}$

$57 \mathrm{~b}$

$56 \mathrm{~b}$

$55 \mathrm{~b}$

$62 \mathrm{~b}$

$61 \mathrm{~b}$

$65 \mathrm{~b}$

$61 \mathrm{~b}$

$64 \mathrm{~b}$

54 b

51 a

45 a

$34 \mathrm{ab}$
$45 \mathrm{c}$

$45 \mathrm{c}$

$45 \mathrm{c}$

$46 \mathrm{c}$

$45 \mathrm{c}$

$47 \mathrm{c}$

$47 \mathrm{c}$

$47 \mathrm{c}$

$50 \mathrm{c}$

$49 \mathrm{c}$

$52 \mathrm{c}$

$65 \mathrm{c}$

$64 \mathrm{~b}$

$47 \mathrm{c}$

$45 \mathrm{~b}$

$35 \mathrm{~b}$

$32 \mathrm{~b}$

Mean rating (0-100 scale $)^{\mathrm{w}}$

$\begin{array}{lll}72 \mathrm{a} & 54 \mathrm{~b} & 37 \mathrm{c} \\ 83 \mathrm{a} & 59 \mathrm{~b} & 40 \mathrm{c} \\ 77 \mathrm{a} & 60 \mathrm{~b} & 46 \mathrm{c}\end{array}$

${ }^{\mathrm{z}}$ Home improvement center was defined in the survey as Home Depot (Atlanta, GA), Lowes (Moorseville, NC), etc. Mass merchandiser was defined as Walmart (Bentonville, AR), Target (Minneapolis, MN), etc.

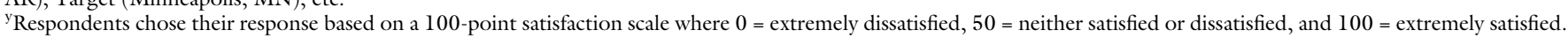
${ }^{\mathrm{x}}$ Letters indicate significance using an analysis of variance with Tukey's honestly significant difference multiple comparison correction. The same letter in a row indicates no significant difference at the 0.10 level, whereas different letters indicate significant differences at the 0.10 level.

${ }^{w}$ Respondents chose their response on a 100 -point importance scale where $0=$ lowest on the market, $50=$ average on market, and $100=$ highest on market. 
production practices. The only exceptions were being a valuable member of the community, home delivery, and other practices, for which IGC and HIC perceptions were not significantly different from each other, as well as lowest price, for which IGCs scored the lowest. Consumers were also more satisfied when IGCs were paying workers a living wage compared with HICs or MMs. Given these findings, it seemed that IGCs were viewed preferably by consumers because of their altruistic business/production practices. These results were similar to scores related to business practices; IGCs received high scores for many of the same practices that respondents indicated were important to them when deciding where to shop, such as knowledgeable staff, customer service, and high-quality plants.

IGCs, like HICs, have significant advantages compared with MMs because of their characteristics that respondents indicated were important to them. HICs and IGCs consistently received higher scores on all rating scales compared with MMs. The only exceptions were competitive prices, other practices, and lowest prices.

Respondents perceived IGCs as having the highest prices, quality, and quality for price, followed by HICs and MMs. This confirmed the anecdotal evidence discussed by Curran (2013), who indicated that IGCs have higher perceived prices and quality. Given these findings, there seems to be clear niches in the market that allow IGC retailers to provide products to a specific socioeconomic clientele. IGCs should concentrate on maintaining high quality because consumers perceive higher quality as valuable. As long as consumers consider quality to be valuable at the IGC level, IGCs should be able to maintain higher prices, which could offset potentially higher costs of stocking plants with higher quality and, therefore, higher wholesale costs compared with HICs or MMs. However, MMs are perceived as having the lowest prices and lowest quality. If MMs strive to expand their market share, then increasing quality could pull the market share away from HICs, especially if a lower price can be maintained. MMs (and HICs) have attempted to increase quality via supply contracts whereby the supplier is responsible for plant care.
IGCs generally have higher satisfaction ratings than HICs and MMs (Table 4). When examining characteristics such as knowledgeable staff and energy-saving practices according to age cohorts, the satisfaction levels indicated that IGCs had higher ratings than HICs or MMs (Table 4). Regarding paying workers a living wage, there were generational differences in satisfaction; Generation X respondents were less satisfied with worker wages paid by IGCs compared with Millennials. Furthermore, Millennials were less satisfied with customer service and high-quality plants at IGCs compared with Baby Boomers. There was agreement across age cohorts regarding satisfaction with customer service and high-quality plants at HICs and MMs. Based on these findings, there was dichotomy in the views across age cohorts and across retailers. As noted by Behe et al. (2016), age cohorts have different preferences.

Price, Quality, AND Quality FOR PRICE ACROSS AGE COHORTS AND RETAILERS. A consistent theme in Tables $2-4$ is that price and quality are important drivers of how a retailer is viewed by consumers. Results presented in Table 3 indicate that IGCs are perceived to have higher prices, high-quality plants, and higher quality for price. As can be seen in Table 5 , this view is shared across age cohorts. Baby Boomers, Generation $\mathrm{X}$ respondents, and Millennials all perceive IGCs as having higher prices, higher quality, and higher quality for the price. Furthermore, HICs are perceived to have higher market prices and quality than MMs.

ORDINARY LEAST SQUARES regression results: Price. When comparing differences between retailers, the OLS model had constant demographics and assessed the impact of other variables (Table 6). As a result, the impact of demographics on the dependent variable of interest could be explained. Starting with price, Generation X and Millennial respondents gave IGCs 6.80 and 9.06 fewer rating points compared to HICs, respectively. Caucasian respondents gave IGCs 9.12 more rating points than HICs. Caucasians also rated IGCs 17.32 points higher than MMs; however, women rated IGCs 6.15 points lower. When comparisons were made between IGCs and HICs and between IGCs and MMs, a $\$ 1000$ increase in the average household income resulted in 0.05 and 0.05 increases in the differences between the IGC price rating compared with the HIC and MM price ratings, respectively.

Regarding plant purchasing, respondents who purchased flowering shrubs rated IGCs higher than both HICs and MMs by 4.16 and 5.28 points, respectively. Respondents who purchased indoor flowering potted plants rated IGCs higher than MMs. Respondents who purchased fruitproducing trees, evergreen trees and shrubs, and shade trees rated MMs higher than IGCs. IGCs had higher scores for the price of nontree plants, but lower scores for the price of trees.

When comparing HICs and MMs, younger respondents gave HICs higher ratings than MMs. Generation $\mathrm{X}$ respondents gave HICs an average of 5.65 more rating points than Baby Boomers, whereas Millennials gave HICs an average of 6.86 more rating points. However, women gave HICs 4.79 fewer points than MMs. In contrast to the IGC models, household income did not have a role in differences associated with HICs and MMs. Respondents who purchased shade trees indicated that MMs had lower prices than HICs.

Ordinary LEAST SQuares REGRESSION RESULTS: QUALITY. Unlike the price models, age did not have much of a role in the perceptions of quality (Table 6). The only exception was Millennials, who perceived HICs as having higher quality than MMs. Caucasian respondents perceived IGCs to have higher quality than both HICs and MMs. With respect to plant purchasing, IGCs were consistently rated as having higher quality across many of the nontree plants. Vegetable and herb buyers perceived IGC quality as higher than that of HICs and MMs. Indoor flowering potted plants, annual flowering, and flowering perennial buyers rated IGCs as having higher quality than MMs. With respect to trees and shrubs, IGCs were rated lower than HICs by evergreen tree and shrub buyers and lower than MMs by fruit-producing tree buyers. Similarly, IGCs seem to struggle with price and quality of trees and shrubs while excelling in quality for nontrees and shrub plants.

Ordinary LEAST SQuares REGRESSION RESULTS: QUALITY FOR 
Production and Marketing Reports

Table 4. Importance of business/production practices associated with specific plant retailers compared across age cohorts as determined by a 2016 survey of plant buyers residing in Connecticut.

\begin{tabular}{|c|c|c|c|}
\hline & Baby Boomer or older ${ }^{z}$ & Generation $\mathrm{X}^{\mathrm{z}}$ & Millennial or younger \\
\hline & \multicolumn{3}{|c|}{ Mean rating $(0-100 \text { scale })^{y}$} \\
\hline \multicolumn{4}{|l|}{ Pay workers a living wage } \\
\hline Home improvement center ${ }^{x}$ & 57 bc & $56 \mathrm{bc}$ & $51 \mathrm{c}$ \\
\hline Mass merchandiser ${ }^{\mathrm{x}}$ & $45 \mathrm{~d}$ & $45 \mathrm{~d}$ & $42 \mathrm{~d}$ \\
\hline \multicolumn{4}{|l|}{ Knowledgeable staff } \\
\hline Mass merchandiser & $45 \mathrm{c}$ & $44 \mathrm{c}$ & $44 \mathrm{c}$ \\
\hline \multicolumn{4}{|l|}{ Use water-conserving practices } \\
\hline Nursery/greenhouse garden center & $62 \mathrm{a}$ & $65 \mathrm{a}$ & 59 a \\
\hline Home improvement center & $53 \mathrm{~b}$ & $53 \mathrm{~b}$ & $52 \mathrm{bc}$ \\
\hline Mass merchandiser & $47 \mathrm{~cd}$ & $45 c$ & $43 \mathrm{c}$ \\
\hline \multicolumn{4}{|l|}{ Organic plants available } \\
\hline Nursery/greenhouse garden center & $63 \mathrm{a}$ & $67 \mathrm{a}$ & $62 \mathrm{a}$ \\
\hline Home improvement center & $51 \mathrm{~b}$ & $55 \mathrm{~b}$ & $53 \mathrm{~b}$ \\
\hline Mass merchandiser & $43 \mathrm{c}$ & $46 \mathrm{c}$ & $45 \mathrm{c}$ \\
\hline \multicolumn{4}{|l|}{ Locally grown plants available } \\
\hline Nursery/greenhouse garden center & $73 \mathrm{a}$ & $71 \mathrm{ab}$ & $67 \mathrm{~b}$ \\
\hline Home improvement center & $58 \mathrm{c}$ & $57 \mathrm{c}$ & $54 \mathrm{c}$ \\
\hline Mass merchandiser & $48 \mathrm{~d}$ & $46 \mathrm{~d}$ & $45 \mathrm{~d}$ \\
\hline \multicolumn{4}{|l|}{ Native plants available } \\
\hline Nursery/greenhouse garden center & $72 \mathrm{a}$ & $69 \mathrm{a}$ & $62 \mathrm{~b}$ \\
\hline Home improvement center & $57 \mathrm{bc}$ & $57 \mathrm{bc}$ & $52 \mathrm{~cd}$ \\
\hline Mass merchandiser & $51 \mathrm{~d}$ & $49 \mathrm{~d}$ & $50 \mathrm{~d}$ \\
\hline \multicolumn{4}{|l|}{ High-quality plants } \\
\hline Nursery/greenhouse garden center & $77 \mathrm{a}$ & $73 \mathrm{ab}$ & $69 \mathrm{~b}$ \\
\hline Home improvement center & $62 c$ & $62 c$ & $59 \mathrm{c}$ \\
\hline Mass merchandiser & $50 \mathrm{~d}$ & $49 \mathrm{~d}$ & $46 \mathrm{~d}$ \\
\hline \multicolumn{4}{|l|}{ A lot of varieties available } \\
\hline Nursery/greenhouse garden center & $76 \mathrm{a}$ & $72 \mathrm{ab}$ & $67 \mathrm{bc}$ \\
\hline Home improvement center & $65 \mathrm{c}$ & $65 c$ & $63 c$ \\
\hline Mass merchandiser & $52 \mathrm{~d}$ & $53 \mathrm{~d}$ & $48 \mathrm{~d}$ \\
\hline \multicolumn{4}{|l|}{ Lowest price } \\
\hline Nursery/greenhouse garden center & $53 \mathrm{~d}$ & $54 \mathrm{~cd}$ & $50 \mathrm{~d}$ \\
\hline Home improvement center & $61 \mathrm{~b}$ & $61 \mathrm{~b}$ & $59 \mathrm{bc}$ \\
\hline Mass merchandiser & $63 \mathrm{ab}$ & $67 \mathrm{a}$ & $65 \mathrm{ab}$ \\
\hline \multicolumn{4}{|l|}{ Competitive prices } \\
\hline Nursery/greenhouse garden center & $61 \mathrm{ab}$ & $59 \mathrm{bc}$ & $55 \mathrm{c}$ \\
\hline Home improvement center & $66 \mathrm{a}$ & $65 \mathrm{a}$ & $61 \mathrm{abc}$ \\
\hline Mass merchandiser & $66 \mathrm{a}$ & $65 \mathrm{a}$ & $61 \mathrm{abc}$ \\
\hline \multicolumn{4}{|l|}{ Have brands I want } \\
\hline Nursery/greenhouse garden center & $61 \mathrm{a}$ & $59 \mathrm{ab}$ & 54 bcd \\
\hline Home improvement center & $53 \mathrm{~cd}$ & $55 \mathrm{bc}$ & $56 \mathrm{abc}$ \\
\hline Mass merchandiser & $46 \mathrm{e}$ & $48 \mathrm{e}$ & $48 \mathrm{de}$ \\
\hline
\end{tabular}


Table 4. (Continued) Importance of business/production practices associated with specific plant retailers compared across age cohorts as determined by a 2016 survey of plant buyers residing in Connecticut.

\begin{tabular}{lcc} 
Baby Boomer or older $^{\mathrm{z}}$ & ${\text { Generation } \mathrm{X}^{\mathrm{z}}}^{\mathrm{M}}$ & Millennial or younger $^{\mathrm{z}}$ \\
\hline Mean rating $\left(0-100\right.$ scale $^{\mathrm{y}}$ &
\end{tabular}

Valuable member of community

Nursery/greenhouse garden center

Home improvement center

Mass merchandiser

ean rating $(0-100 \text { scale })^{y}$

Home delivery

Nursery/greenhouse garden center

Home improvement center

Mass merchandiser

Other

Nursery/greenhouse garden center 35

Home improvement center

Mass merchandiser

$\begin{array}{lll}57 \mathrm{a} & 58 \mathrm{a} & 55 \mathrm{ab} \\ 51 \mathrm{bc} & 51 \mathrm{bcd} & 49 \mathrm{bcde} \\ 46 \mathrm{cde} & 45 \mathrm{de} & 42 \mathrm{e} \\ & & \\ 45 \mathrm{abc} & 48 \mathrm{ab} & 45 \mathrm{abc} \\ 41 \mathrm{~cd} & 46 \mathrm{abc} & 50 \mathrm{a} \\ 29 \mathrm{e} & 37 \mathrm{~d} & 41 \mathrm{bcd} \\ & & \\ 35 \mathrm{a} & 38 \mathrm{a} & 35 \mathrm{a} \\ 33 \mathrm{a} & 35 \mathrm{a} & 33 \mathrm{a} \\ 31 \mathrm{a} & 32 \mathrm{a} & 31 \mathrm{a}\end{array}$

${ }^{2}$ Baby Boomers or older (born 1964 or earlier), Generation X (born between 1965 and 1984), and Millennials or younger (born 1985 or after).

${ }^{y}$ Respondents chose their response based on a 100 -point satisfaction scale where $0=$ extremely dissatisfied, $50=$ neither satisfied or dissatisfied, and $100=$ extremely satisfied.

${ }^{\mathrm{x}}$ Home improvement center was defined in the survey as Home Depot (Atlanta, GA), Lowes (Moorseville, NC), etc. Mass merchandiser was defined as Walmart (Bentonville,

AR), Target (Minneapolis, MN), etc.

wLetters indicate significance using an analysis of variance with Tukey's multiple comparison correction. The same letter in business production practices row/column within each business/production practice indicates no significant difference at the 0.05 level, whereas different letters indicate significant differences at the 0.05 level.

Table 5. Importance of price/quality associated with specific plant retailers compared across age cohorts as determined by a 2016 survey of plant buyers residing in Connecticut.

\begin{tabular}{|c|c|c|c|}
\hline & \multicolumn{3}{|c|}{ Price } \\
\hline & Baby Boomer or older ${ }^{z}$ & Generation $\mathrm{X}^{\mathrm{z}}$ & Millennial or younger ${ }^{\mathrm{z}}$ \\
\hline & \multicolumn{3}{|c|}{ Mean rating $(0-100 \text { scale })^{y}$} \\
\hline Home improvement center ${ }^{\mathrm{x}}$ & $50 \mathrm{c}$ & $57 \mathrm{~b}$ & $59 \mathrm{~b}$ \\
\hline \multirow[t]{2}{*}{ Mass merchandiser ${ }^{\mathrm{x}}$} & $34 \mathrm{e}$ & 38 de & $41 \mathrm{~d}$ \\
\hline & \multicolumn{3}{|c|}{ Quality } \\
\hline Nursery/greenhouse garden center & $83 \mathrm{a}$ & $84 \mathrm{a}$ & $82 \mathrm{a}$ \\
\hline Home improvement center & $57 \mathrm{~b}$ & $61 \mathrm{~b}$ & $62 \mathrm{~b}$ \\
\hline \multirow[t]{3}{*}{ Mass merchandiser } & $39 \mathrm{c}$ & $42 \mathrm{c}$ & $39 \mathrm{c}$ \\
\hline & \multicolumn{3}{|c|}{ Quality for price paid } \\
\hline & Baby Boomer or older & Generation $\mathrm{X}$ & Millennial and Generation $\mathrm{Z}$ \\
\hline
\end{tabular}

${ }^{2}$ Baby Boomers or older (born 1964 or earlier), Generation X (born between 1965 and 1984), and Millennials or younger (born 1985 or after).

${ }^{\mathrm{y}}$ Respondents chose their response based on a 100 -point importance scale where $0=$ lowest on market, $50=$ market average, and $100=$ highest on market.

${ }^{\mathrm{x}}$ Home improvement center was defined in the survey as Home Depot (Atlanta, GA), Lowes (Moorseville, NC), etc. Mass merchandiser was defined as Walmart (Bentonville, AR), Target (Minneapolis, MN), etc.

wLetters indicate significance using an analysis of variance with Tukey's multiple comparison correction. The same letter in a row or column within price, quality, or quality for price indicates no significant difference at the 0.05 level, whereas different letters indicate significant differences at the 0.05 level.

PRICE PAID. Consumers rarely consider price and quality independently. Therefore, the insights gained by considering quality for the price are critical to understanding consumer perceptions across retailers. Regarding age, Millennials rated HICs 6.45 points higher than IGCs, and they rated HICs 5.01 points higher than MMs (Table 6). Caucasians rated IGCs 6.68 points higher than MMs. Respondents with detached homes rated IGCs higher than both HICs and MMs (4.13 and 6.72, respectively).

After examining plant purchasing variables, annual flowering plants, herbs, and indoor flowering potted plant buyers rated MMs lower in quality for price compared with IGCs and HICs. Evergreen tree and shrub buyers rated IGCs lower than HICs regarding quality for price. Shade tree buyers rated MMs as having higher quality for price compared with HICs.

\section{Conclusions}

Understanding the roles of business and production practices is essential for firms to make accurate marketing decisions. This study examined the role of various business and production practices across retailers and across age cohorts. The perceptions of 


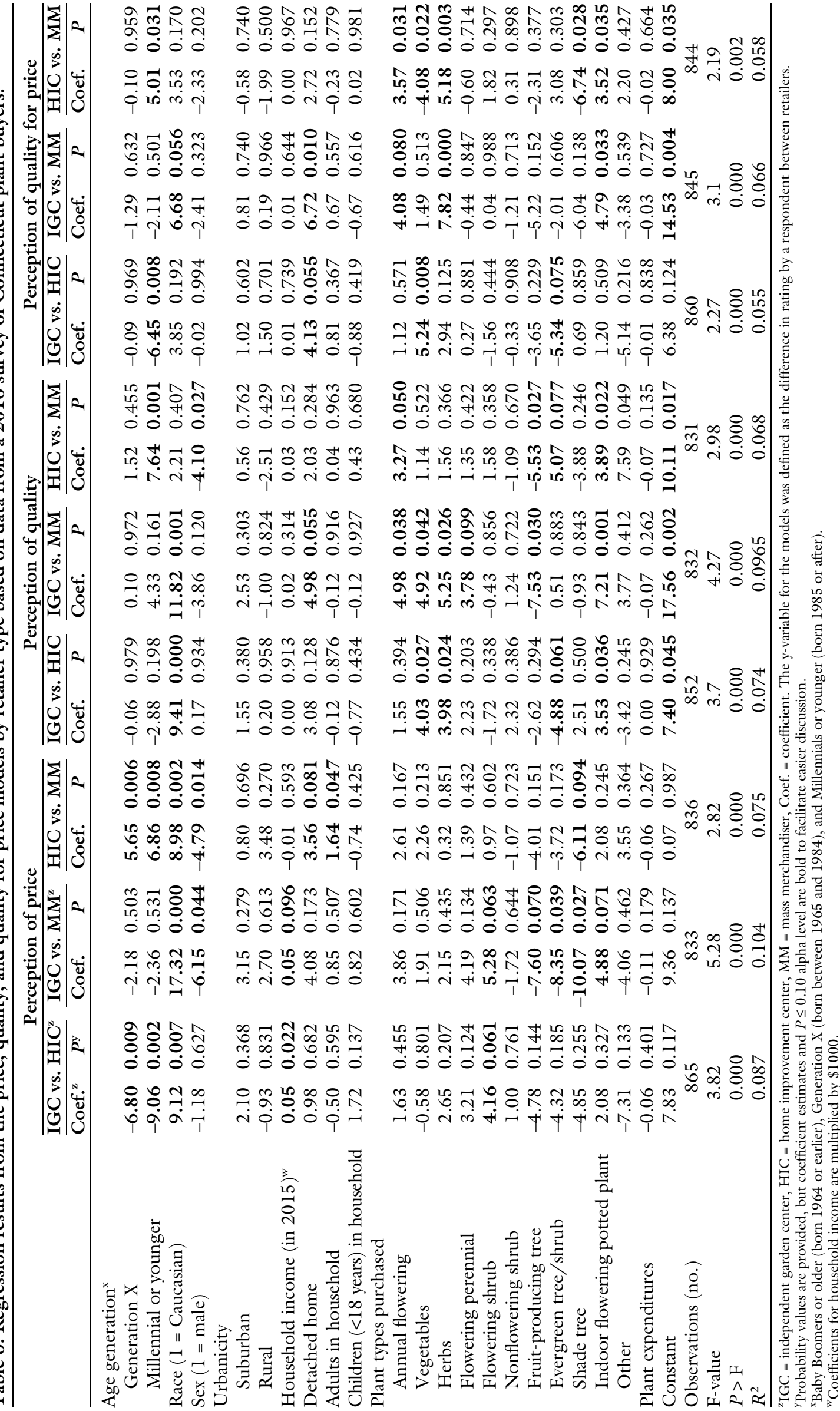


respondents regarding price, quality, and quality for price were evaluated, with an emphasis on gaining a better understanding of how demographics influence these perceptions.

Results indicated that customer service, knowledgeable staff, and highquality plants are important factors when consumers are deciding where to shop. These results are similar to those of Behe and Barton (2000) and Safley and Wohlgenant (1995), who indicated that high quality, price, and customer service were important characteristics of retailers. Furthermore, IGCs, HICs, and MMs were perceived differently across age cohorts. Survey respondents were more satisfied with the customer service, knowledgeable staff, and highquality plants of IGC, then of HICs, and then of MMs. The age cohort did make a difference in these perceptions. Finally, the types of plants that respondents had purchased in the past had a role in how the IGCs, HICs, and MMs were viewed regarding price, quality, and quality for price.

This research yielded several important implications. First, retailers need to be aware that not only demographics but also past purchasing shape perceptions. MMs tended to be perceived as having better prices, quality, and quality for price for trees and shrubs; however, IGCs and HICs tended to be perceived as better for nontrees and shrubs. Second, this research provided a clear picture of how retailers are perceived in Connecticut. Similar to the results of Safley and Wohlgenant (1995), we found that MMs are seen as lower price/lower quality, IGCs are seen as higher price/higher quality, and HICs are seen as middle price/middle quality. Noting these differences, firms wishing to expand their market share may need to rehabilitate their image to take the market share from another retailer.

Demographics can be used to advance marketing strategies for the various retail outlets depending on their competitors. For instance, higher-income households perceive IGCs as having higher prices than HICs and MMs, but with no differences in quality or quality for price. IGCs operating in higher-income areas or that have higher-income clientele should work to improve quality to justify their higher prices. However, HICs and MMs competing with
IGCs in higher-income areas should advertise their lower prices because, at the time of this study, no quality differences were perceived between retailers. Furthermore, IGCs that have more Caucasian clientele need to realize that their prices are perceived as higher than those offered by HICs and MMs, but that their quality is also perceived as higher. However, quality for price was only higher for IGCs when compared with MMs. Based on these results, HICs with more Caucasian clientele should stress that IGCs may not offer quality for the price. However, MMs should focus on competing with HICs because IGCs are perceived to have better quality and quality for price.

\section{Literature cited}

Behe, B.K. and S. Barton. 2000. Consumer perceptions of product and service quality attributes in six U.S. states. HortScience 18:71-78.

Behe, B.K., P. Huddleston, and L. Sage. 2016. Age cohort influences brand recognition, awareness, and likelihood to buy vegetable and herb transplants. HortScience 51:145-151.

Campbell, B., B. Brewer, K. Wolfe, and S.P. Kane. 2017a. Impacts of the great recession and drought on the environmental horticulture industry. Univ. Georgia Circ. 1119. 2 Sept. 2018. <https://secure. caes.uga.edu/extension/publications/ files/pdf/C\%201119_3.PDF>.

Campbell, B., H. Khachatryan, and A. Rihn. 2017b. Pollinator friendly plants: Reasons for and barriers to purchase. HortTechnology 27:831-839.

Chao, L. 2016. Online shoppers want delivery faster, cheaper, survey shows. 5 Sept. 2018. <https://www.wsj.com/ articles/online-shoppers-want-deliveryfaster-cheaper-survey-shows1465851072>.

Curran, E. 2013. Experts compare flowers from independents versus big-box retailers. 5 Sept. 2018. <https://chicago. cbslocal.com/2013/05/10/expertscompare-flowers-from-independentsversus-big-box-retailers/>.

Danziger, P.N. 2018. The race is on for grocery delivery, but most customers want to shop in stores. 5 Sept. 2018. <https://www.forbes.com/sites/ pamdanziger $/ 2018 / 05 / 22 /$ race-is-onfor-last-mile-grocery-delivery-but-aregrocery-stores-losing-the-biggeropportunity/\#437c21e73d81>.
Flagg, L.A., B. Sen, M. Kilgore, and J.L. Locher. 2013. The influence of gender, age, education, and household size on meal preparation and food shopping responsibilities. Public Health Nutr. 17: 2061-2070.

Garden Research. 2010. National Gardening Survey. Garden Research, Burlington, VT.

Garden Research. 2017. National Gardening Survey. Garden Research, Burlington, VT.

Garden Research. 2018. National Gardening Survey. Garden Research, Burlington, VT.

Hall, C. 2010. Making cents of green industry economics. HortTechnology 20: 832-835.

Huber, P.J. 1967. The behavior of maximum likelihood estimates under nonstandard conditions. Proc. Fifth Berkeley Symp. Mathematical Stat. Probability. Vol. 1. Univ. California Press, Berkeley, CA. p. 221-233.

Leaman, C. 2018. What will it take for consumers to open their homes (and their refrigerators) to a stranger? 5 Sept. 2018. <https://www.forbes.com/sites/ forbestechcouncil/2018/05/07/whatwill-it-take-for-consumers-to-open-theirhomes-and-their-refrigerators-to-astranger/\#608c3aa77d2b>.

Lopez, R.A., N. Plesha, and B. Campbell. 2015. Northeast economic engine: Agriculture, forest products and commercial fishing. 5 Sept. 2018 . <http:// zwickcenter.uconn.edu/outreach reports_10_1981703122.pdf>.

Lutz, A. 2015. How Nike shed its sweatshop image to dominate the shoe industry. 5 Sept. 2018.<https://www. businessinsider.com/how-nike-fixed-itssweatshop-image-2015-6>.

Manlapas, M. 2018. How consumers view online delivery options. 5 Sept. 2018. <https://www.digitalcommerce360. com $/ 2018 / 07 / 25 /$ how-consumersview-online-delivery-options $/>$.

Meyersohn, N. 2018. What higher wages means for Domino's and McDonald's. 5 Sept. 2018. <https://money.cnn.com/ 2018/06/22/news/companies/olivegarden-mcdonalds-wendys-dominoschipotle/index.html>.

Perez, M., M. Palma, B. Behe, and C. Hall. 2016. Structural breaks and future growth of the green industry. J. Environ. Hort. 34:52-55.

Rihn, A. and H. Khachatryan. 2016. Does consumer awareness of neonicotinoid pesticides influence their preferences for plants? HortScience 51:388-393. 


\section{Production and Marketing Reports}

Safley, C.D. and M.K. Wohlgenant. 1995. Factors influencing consumers' selection of garden centers. J. Agribusiness 13:33-50.

Satterthwaite, L.N., J.J. Haydu, and A.W. Hodges. 2006. Consumer purchasing habits of environmental horticulture products in Florida. J. Environ. Hort. $24: 68-73$.

State of Connecticut. 2011. Public act 11189. 5 Sept. 2018. <https://www.cga.ct. gov $/ 2011 / \mathrm{ACT} / \mathrm{Pa} / \mathrm{pdf} / 201 \mathrm{PA}-$ 00189-R00HB-05508-PA.pdf>.

Sparks, B. 2017. Farwest 2017 spotlights latest insights in horticulture from growing to retailing. 5 Sept. 2018. <https:// www.green hous egrower.com / management/farwest-2017-spotlightslatest-insights-in-horticulture-fromgrowing-to-retailing $>$.
Tuttle, B. 2016. Imagine that! Walmart pays workers better and the shopping experience improves. 5 Sept. 2018.<http:// time.com/money/4533276/walmarte mployee-pay-customer-servicesatisfaction-ratings-sales $/>$.

U.S. Census Bureau. 2010. Community facts. American factfinder. 5 Sept. 2018. <https://factfinder.census.gov/faces/ nav/jsf/pages/community_facts.xhtml? $\operatorname{src}=\mathrm{bkmk}>$.

U.S. Census Bureau. 2017. U.S. Census Bureau quickFacts: Connecticut. 5 Sept. 2018 . <https://www.census.gov/ quickfacts/fact/table/ct,US/ PST045217>

White, H.L., Jr. 1980. A heteroskedasticity-consistent covariance matrix estimator and a direct test for heteroskedasticity. Econometrica 48:817-838.

White, H.L., Jr. 1982. Maximum likelihood estimation of misspecified models. Econometrica 50:1-25.

Wolfe, A. 2013. Christine Lagarde: On top of the world. 5 Sept. 2018. <https:// www.wsj.com/articles/christine-lagardeon-top-of-the-world-1380934428>.

Yue, C. and B.K. Behe. 2008. Estimating U.S. consumers' choice of floral retail outlets. HortScience 43:764-769.

Zepeda, L. 2009. Which little piggy goes to market? Characteristics of US farmers' market shoppers. Intl. J. Consum. Stud. $33: 250-257$. 